\title{
Gerak Dasar Kids Atletik Pada Siswa Sekolah Dasar di Kecamatan Sukun Kota Malang
}

\author{
Salimah Fadilah Inayah*, Siti Nurrochmah \\ Universitas Negeri Malang, Jl. Semarang No. 5 Malang, Jawa Timur, Indonesia \\ *Penulis korespondensi, Surel: salimahfadilah98@gmail.com
}

Paper received: 24-5-2021; revised: 14-6-2021; accepted: 21-6-2021

\begin{abstract}
The research objective was to determine and assess the basic movement abilities of athletic kids of elementary school students in Sukun District, Malang City. The study used a survey design and a research approach in the form of an observation method. The population of elementary schools in the district of Sukun, Malang city, grades 4-5 are 75 students consisting of 3 schools, each school totaling 25 students. Sampling using purposive sampling technique of student candidates for the KOSN Competition totaled 75 students. The results showed that the kangas escape test was in the good category of 30 people ( 40 percent), the jump test results were in the good category 32 people (42.7 percent), the throwing test results were in the less category the number of 40 people (53.3 percent), the results of the formula 1 running test were in the good category with 27 people (36 percent). The conclusion is that the basic athletic ability of elementary school students in Sukun District, Malang City, the type of kanga's escape test is in good category, frog jumping is a good category, turbo throwing is not good category, and formula 1 movement is good category.
\end{abstract}

Keywords: basic movement; elementary school

\begin{abstract}
Abstrak
Tujuan penelitian untuk mengetahui dan mengkaji kemampuan gerak dasar Kids atletik siswa SD di Kecamatan Sukun Kota Malang. Penelitian menggunakan rancangan survei dan pendekatan penelitian berupa metode observasi. Populasi SD di lingkungan Kecamatan Sukun kota Malang kelas 4-5 berjumlah 75 siswa yang terdiri atas 3 sekolah, tiap sekolah berjumlah 25 siswa. Pengambilan sampel menggunakan teknik purposive sampling siswa calon peserta Lomba KOSN berjumlah 75 siswa. Hasil penelitian menunjukkan tes kanga's escape pada kategori baik jumlah 30 orang (40 persen), hasil tes loncat berada di kategori baik jumlah 32 orang (42,7 persen), hasil tes lempar berada pada di kategori kurang jumlah 40 orang (53,3 persen), hasil tes lari formula 1 berada di kategori baik jumlah 27 orang (36 persen). Simpulan bahwa kemampuan gerak dasar kids atletik siswa SD di Kecamatan Sukun Kota Malang jenis tes kanga's escape kategori baik, loncat katak kategori baik, lempar turbo kategori kurang baik, dan gerakan formula 1 kategori baik.
\end{abstract}

Kata kunci: gerak dasar; sekolah dasar

\section{Pendahuluan}

Olahraga saat ini sudah cukup dikenal oleh masyarakat Indonesia dan menjadi salah satu aktivitas yang banyak digemari oleh masyarakat pada umumnya, baik di perkotaan maupun pelosok tanah air. Kegiatan berolahraga sangat digemari oleh masyarakat dari berbagai kalangan, mulai dari anak-anak, remaja, orang dewasa hingga orang tua. Banyak masyarakat memilih hidup sehat dengan berolahraga, mereka menyisihkan sedikit waktu seperti hari libur, pagi hari, sore hari maupun malam hari setelah melakukan aktivitas sehari-hari seperti bekerja. Undang-undang Sistem Keolahragaan Nasional (dalam Kemenpora, 2009) mengatakan bahwa olahraga adalah segala kegiatan yang sistematis untuk mendorong, membina serta mengembangkan potensi jasmani, rohani dan sosial. 
Kemenpora (dalam Mardiana, dkk. 2014) berpendapat bahwa olahraga adalah bentukbentuk kegiatan jasmani yang terdapat dalam aktivitas permainan, perlombaan, dan kegiatan jasmani yang intensif dalam rangka upaya melakukan aktivitas rekreasi, kemenangan dan prestasi optimal. Khairuddin (2017) mengatakan "olahraga secara umum adalah suatu aktivitas fisik dan psikis seseorang yang dapat menjaga dan meningkatkan kualitas tubuh seseorang". Olahraga juga merupakan sekelompok gerak yang teratur dan terencana untuk mempertahankan dan meningkatkan kemampuan gerak seseorang. Mirhan,dkk. (2016) olahraga tidak hanya memfokuskan pada faktor fisik, melainkan juga melatih mental dan moral seseorang.

Macam aktivitas fisik yang termasuk dalam kegiatan olahraga adalah aktivitas olahraga senam, renang, basket, bolavoli, sepakbola, badminton, tenis meja, tenis lapangan, atletik dan lain-lain. Diantara jenis olahraga tersebut olahraga atletik dikatakan sebagai olahraga tertua atau Mother of Sport. Oleh sebab itu atletik disebut induk dari semua cabang olahraga karena gerak dasar pada semua cabang olahraga ada di dalam cabang olahraga atletik.

Pemerintah melalui Kemendiknas sejak tahun 2010 memiliki program penyelenggaraan kejuaraan khusus pelajar antar jenjang satuan pendidikan, bernama Olimpiade Olahraga Siswa Nasional atau 02SN, yang meliputi tingkat SMA atau sederajat, 02SN khusus pelajar SLTP dan O2SN khusus lingkungan pelajar dari jenjang SD. Cabang olahraga yang diperlombakan atau dipertandingkan, menurut Purnama (2010) pada kejuaraan 02SN terdapat beberapa cabang olahraga yang diperlombakan diantaranya yaitu bola voli, sepak bola, renang, bulu tangkis, karate, tenis meja, tenis lapangan, catur, senam, pencak silat, bridge, sepak takraw, basket, futsal, atletik. Diantara cabang olahraga tersebut cabang olahraga atletik selalu diperlombakan, karena cabang olahraga atletik cukup sederhana tidak membutuhkan biaya banyak dan tidak memerlukan peralatan dalam perlombaan.

Sejak dari awal diadakannya Olimpiade Olahraga Siswa Nasional tingkat sekolah dasar tidak menggunakan nomor-nomor umum di dalam atletik, tetapi nomor-nomor yang digunakan yaitu nomor-nomor yang dikhususkan untuk anak-anak pada jenjang SD yaitu Kids atletik. Kids Athletics merupakan suatu cabang olahraga dari cabang olahraga atletik yang telah dimodifikasi untuk siswa Sekolah Dasar. Nomor-nomor yang dilombakan meliputi lari, lempar, loncat, dan terdapat senam lantai seperti roll depan. Nomor yang dilombakan diantaranya yaitu kanga's escape, loncat katak, lempar turbo, dan formula 1. Adapun gerak dasar dalam kids atletik meliputi nomor lari, loncat dan lempar.

Sehubungan dengan penyelenggaraan kegiatan Kompetisi Olahraga Siswa Nasional (sebelum terjadi Covid-19), Kemendikbud Kota Malang menyelenggarakan kegiatan Kompetisi Olahraga Siswa Nasional pada tanggal 18 Februari 2020 di lingkungan Kecamatan Sukun Kota Malang. Untuk menghadapi even tersebut, seharusnya tiap sekolah menyelenggarakan seleksi unjuk kerja pada beberapa cabang olahraga yang dipertandingkan melalui pengukuran dalam bentuk tes unjuk kerja fisik. Fungsi tes fisik untuk mengetahui kondisi fisik siswa (Khomaruddin, 2016) khususnya kondisi gerak dasar pada cabang olahraga atletik yaitu gerak dasar Kids Atletik. Kondisi fisik yang prima akan berdampak positif pada prestasi (Hidayat, 2014).

Namun pada kenyataannya, selama ini beberapa sekolah khususnya sekolah dasar belum pernah guru PJOK mengadakan seleksi melalui pengukuran bentuk tes gerak dasar Kids Atletik untuk persiapan mengikuti Kompetisi Olahraga Siswa Nasional Kota Malang. 
Melakukan pengukuran bentuk tes penting dilakukan karena hasil tes dapat digunakan sebagai dasar atau tolak ukur untuk menentukan langkah-langkah pembinaan selanjutnya (Nurrochmah, 2016). Untuk mengikuti atau menghadapi kegiatan tersebut, Sekolah Dasar di lingkungan Kecamatan Sukun mengadakan seleksi pada berbagai cabang olahraga terutama cabang olahraga atletik berupa tes gerak dasar Kids Atletik.

Peneliti tertarik mengadakan seleksi melalui tes gerak dasar Kids Atletik untuk menghadapi perlombaan Kompetisi Olahraga Siswa Nasional. Sehubungan dengan Sekolah Dasar di Kecamatan Sukun Kota Malang belum pernah mengadakan seleksi untuk mengetahui kemampuan siswa yang akan mengikuti lomba Kompetisi Olahraga Siswa Nasional pada cabang olahraga atletik Kids atletik, maka peneliti tertarik untuk meneliti masalah kemampuan gerak dasar Kids atletik yang belum pernah dilakukan tes unjuk kerja fisik melalui penelitian tentang survei kemampuan gerak dasar kids atletik pada siswa Sekolah Dasar di Kecamatan Sukun Kota Malang. Tujuan penelitian untuk mengetahui dan mengkaji kondisi gerak dasar kids atletik pada siswa SD di lingkungan Kecamatan Sukun Kota Malang.

\section{Metode}

Penelitian menggunakan rancangan survei bentuk deskriptif kuantitatif dan pendekatan penelitian berupa metode observasi. Populasi dalam penelitian ini berjumlah 75 siswa yang terdiri dari 3 Sekolah Dasar, tiap Sekolah Dasar berjumlah 25 siswa yang terdiri atas siswa kelas 4 dan kelas 5. Pengambilan sampel penelitian menggunakan teknik purposive sampling pada siswa sekolah dasar di Kecamatan Sukun Kota Malang yang berjumlah 75 orang. Instrumen penelitian yang digunakan berupa instrumen tes dan nontes. Tes yang digunakan berupa tes kemampuan gerak dasar Kids atletik yang mencakup (a) kanga'a escape (b) loncat katak (c) lempar turbo (d) formula 1. Analisis data menggunakan statistika deskriptif. Pengambilan data menggunakan teknik pengukuran bentuk tes yaitu tes fisik. Data yang diperoleh dianalisis dengan menggunakan statistika deskriptif.

\section{Hasil dan Pembahasan}

\subsection{Hasil}

Berdasarkan hasil penelitian data tes kanga's escape, loncat katak, lempar turbo, dan formula 1 pada kelompok putra siswa SD di Kecamatan Sukun Kota Malang yang berjumlah 40 siswa memperoleh hasil dari tes kanga's escape dengan nilai maksimum 15,14 detik, nilai minimum 23,13 detik, nilai mean 18,63 detik, median 17,46 detik, dan modus 22,56 detik. Sedangkan hasil tes loncat katak memperoleh hasil nilai maksimum 5,97 meter, nilai minimum 2,19 meter, nilai mean 4,35 meter, median 4,71 meter, dan modus 5,34 meter. Hasil lempar turbo memperoleh hasil nilai maksimum 16,80 meter, nilai minimum 3,97 meter, nilai mean 9,23 meter, median 9,80 meter, dan modus 11,42 meter. Hasil dari tes formula 1 memperoleh hasil nilai maksimum 19,30 detik, nilai minimum 26,03 detik, nilai mean 22,55 detik, median 21,88 detik, dan modus 20,70 detik.

Hasil penelitian data tes kanga's escape, loncat katak, lempar turbo, dan formula 1 pada kelompok putri siswa SD di Kecamatan Sukun Kota Malang yang berjumlah 35 siswa memperoleh hasil dari tes kanga's escape dengan nilai maksimum 16,16 detik, nilai minimum 21,87 detik, nilai mean 18,92 detik, median 18,69 detik, dan modus 18,69 detik. Sedangkan hasil tes loncat katak memperoleh hasil nilai maksimum 5,31 meter, nilai minimum 2,79 meter, nilai mean 4,15 meter, median 4,31 meter, dan modus 4,21 meter. Hasil lempar turbo 
memperoleh hasil nilai maksimum 12,98 meter, nilai minimum 4,29 meter, nilai mean 6,77 meter, median 6,44 meter, dan modus 4,29 meter. Hasil dari tes formula 1 memperoleh hasil nilai maksimum 20,53 detik, nilai minimum 26,13 detik, nilai mean 23,58 detik, median 23,49 detik, dan modus 25,19 detik.

Hasil dari penelitian keseluruhan pada kelompok putra dan putri siswa SD di Kecamatan Sukun Kota Malang, menunjukkan tes kanga's escape pada kategori baik jumlah 30 orang (40\%), hasil tes loncat berada pada kategori baik jumlah 32 orang $(42,7 \%)$, hasil tes lempar berada pada kategori kurang jumlah 40 orang $(53,3 \%)$, hasil tes lari formula 1 berada pada kategori baik jumlah 27 orang (36\%).

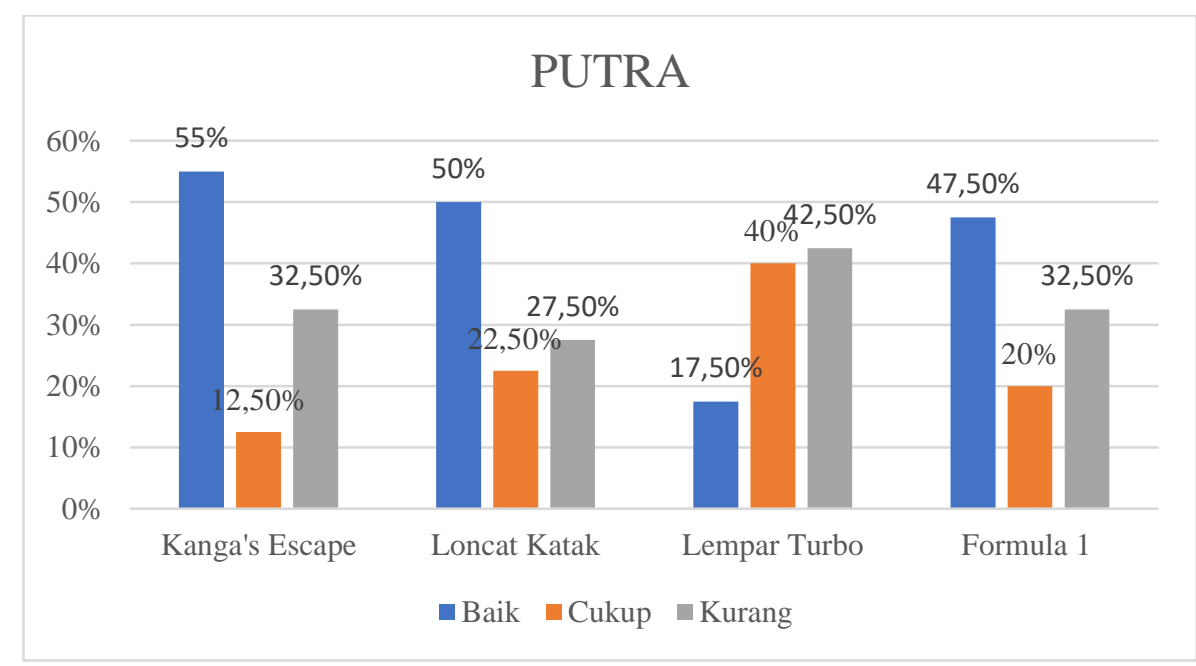

\section{Gambar 1. Grafik Hasil Kriteria Tes Kids Atletik Kelompok Putra Siswa SD di Kecamatan} Sukun Kota Malang

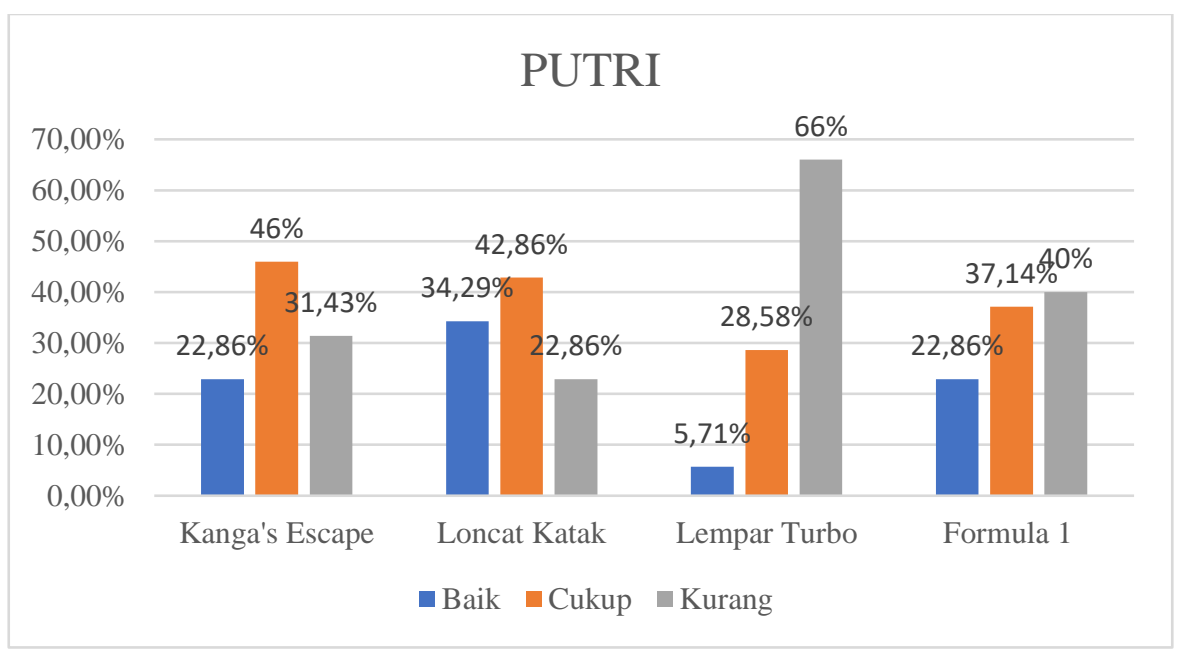

Gambar 2. Grafik Hasil Kriteria Tes Kids Atletik Kelompok Putri Siswa SD di Kecamatan Sukun Kota Malang 


\subsection{Pembahasan}

Berdasarkan hasil analisis data, pada gerak dasar lari kids atletik dominan pada kategori norma baik. Secara keseluruhan capaian hasil tes pada kemampuan gerak dasar kids atletik siswa SD di Kecamatan Sukun Kota Malang jenis tes kanga's escape berada pada kategori baik, loncat katak kategori baik, lempar turbo kategori kurang, dan formula 1 kategori baik. Kategori norma tersebut dibuat berdasar data yang diperoleh dari Siswa yang mengikuti tes gerak dasar kemampuan Kids Atletik khusus pada siswa SD di Kecamatan Sukun. Jika menggunakan standar yang ditentukan oleh PASI (Persatuan Atletik Seluruh Indonesia) maka hasil tersebut belum mencapai standar pada level 1-4.

Yang menyebabkan siswa belum banyak mencapai level 4 (level) untuk di lingkungan siswa SD adalah siswa jarang diberikan tes tersebut dan siswa belum mengikuti pembinaan latihan sehingga siswa masih belum bisa mencapai level 4. Yang sangat berperan pada capaian tersebut adalah kondisi fisik anak yang masih berada pada usia sekolah dan tidak semua peserta tes memiliki pengalaman mengikuti pembinaan berupa latihan-latihan yang diselenggarakan oleh sekolah melalui kegiatan ekstrakurikuler. Latihan sangat dibutuhkan dalam unjuk kerja fisik untuk mencapai penampilan yang optimal dalam mengikuti perlombaan atau kejuaraan.

Latihan (training) merupakan proses yang dilakukan secara sadar untuk melakukan aktivitas secara berulang-ulang dengan tujuan meningkatkan prestasi secara sistematis yang dilaksanakan sepanjang tahun dengan metode yang tepat dan sasaran yang jelas, didukung oleh sarana dan prasarana yang baik serta hasil latihan dapat dievaluasi atau diukur berdasarkan prinsip-prinsip latihan yang dilakukan pada kompetisi yang terencana (Hidayat, 2014). Plowman dan Smith (2017) latihan adalah suatu proses berlatih yang harus ditingkatkan oleh setiap individu dan prinsip latihan diterapkan secara benar dan dilakukan secara sistematis. Emral (2017) latihan adalah aktivitas untuk meningkatkan keterampilan dalam berolahraga menggunakan peralatan olahraga yang sesuai dengan cabang olahraganya.

Berarti yang dimaksud latihan atau pelatihan adalah suatu proses kegiatan yang dilakukan oleh seseorang untuk mencapai tingkat kemampuan yang tinggi dalam aktivitas olahraga. Kegiatan pelatihan yang dilakukan sebaiknya memperhatikan beberapa aspek pada diri masing-masing siswa khususnya yang berpengaruh pada aspek yang berhubungan peningkatan prestasi, seperti usia dan tingkat pertumbuhan dan perkembangan dan kematangan siswa (Sugiharto, 2014). Siswa SD dunianya adalah dunia bermain, sehingga aktivitas latihan yang diberikan sebaiknya berbasis bermain dan menyenangkan, dengan demikian siswa dapat terlibat aktif dalam kegiatan latihan (Mardiana, dkk., 2014).

Jika menghendaki keterampilan kemampuan dasar-dasar gerak Kids Atletik siswa berada pada kriteria baik, melakukan gerakan latihan adalah penting dilakukan agar tubuh mampu melakukan gerakan dengan lancar dan memperoleh hasil sesuai yang diharapkan ketika melakukan unjuk kerja lomba. Hasil latihan-latihan rutin akan terdampak pada capaian kriteria baik.

Pada penelitian yang dilakukan oleh Meirawati \& Nurrochmah (2020) tentang kemampuan kecepatan gerak dan daya ledak otot siswa PPLP Jatim di Kediri cabang olahraga atletik, kesimpulan hasil penelitian bahwa kemampuan kecepatan gerak dominan pada kriteria 
baik, hal tersebut wajar karena siswa PPLP secara rutin melakukan latihan yang terprogram, sistematis, berkelanjutan, dan pada saat latihan lebih difokuskan pada kondisi fisik.

Pada komponen tes loncat bentuk tes loncat katak kelompok putra memperoleh ratarata (mean) 4,35 meter, modus 5,34 meter dan normatif dominan berada pada kriteria baik berjumlah 20 orang $(50,00 \%)$ dari jumlah keseluruhan 40 orang, dan pada kelompok putri rata-rata (mean) 4,15 meter, modus 4,21 meter dan normatif berada pada kriteria baik berjumlah 12 orang $(34,29 \%)$ dari jumlah keseluruhan 35 orang.

Meirawati \& Nurrochmah (2020) kesimpulan dari hasil penelitian dilaporkan bahwa daya ledak otot tungkai dominan berada pada kriteria baik sekali. Sedangkan pada hasil penelitian tes loncat katak dominan berada pada kategori baik, hal tersebut perlu dipertahankan dan lebih ditingkatkan lagi. Untuk meningkatkan kemampuan fisik, terdapat macam-macam bentuk latihan yang diperuntukkan pada siswa SD dan untuk meningkatkan Kids Atletik yang dilakukan oleh Septiria, dkk. (2020) yaitu melakukan penelitian tentang lompat secara vertikal (lompat tali) dan secara horizontal (ladder drill) yang melibatkan otototot rangka. Hasil penelitian dilaporkan bahwa model latihan lompat tali berpasangan dan ladder drill dapat meningkatkan kemampuan gerak dasar kids athletic siswa. Sedangkan hasil uji analisis varian setiap unsur kids athletic $>$ sig. alpha 0.05. Berarti ada perbedaan yang signifikan antara model latihan atletik lompat tali berpasangan dengan ladder drill terhadap peningkatan Kids athletic siswa. Berdasarkan temuan penelitian, kedua model latihan tersebut dapat dijadikan alternatif model latihan yang variatif untuk mengembangkan olahraga atletik di sekolah khususnya di lingkungan siswa SD.

Hindriani (2018) melakukan penelitian tentang kemampuan gerak dasar kids atletik pada siswa SD di Kota Bengkulu, kesimpulan hasil penelitian bahwa seluruh SD di Kota Bengkulu berkategori "sangat kurang" atau sebesar 44,9\%. Hal tersebut dikarenakan belum ada di dalam kurikulum sehingga guru mengenal dalam tes tersebut. Berdasarkan data yang telah dikonversi ke dalam tabel norma kriteria tes pada peserta tes keseluruhan, pada komponen lari rintangan yang diperoleh dari tes kanga's escape dengan rata-rata (mean) 18,63 detik, modus 22,56 detik dan normative berada pada kriteria baik berjumlah 22 orang (55\%) dari jumlah keseluruhan 40 orang, dan pada kelompok putri rata-rata (mean) 18,92 detik, modus 18,69 detik dan normatif berada pada kriteria cukup berjumlah 16 orang (46\%) dari jumlah keseluruhan 35 orang.

Komponen tes lempar bentuk tes lempar turbo kelompok putra memperoleh rata-rata (mean) 9,23 meter, modus 11,42 meter dan normatif berada pada kriteria tidak baik berjumlah 17 orang $(42,50 \%)$ dari jumlah keseluruhan 40 orang, dan pada kelompok putri rata-rata (mean) 6,77 meter, modus 4,29 meter dan normatif berada pada kriteria tidak baik berjumlah 23 orang (66\%) dari jumlah keseluruhan 35 orang.

Rumini (2014) melakukan penelitian tentang pembelajaran permainan kids' athletics sebagai wujud pengembangan gerak dasar atletik pada anak-anak, kesimpulan hasil penelitian dilaporkan bahwa peralatan permainan kids athletics tidak memiliki standar yang baku, sehingga dalam permainan ini dapat menggunakan peralatan yang sudah tidak terpakai di lingkungan sekitar kita. Jadi untuk latihan pada komponen tes lempar dapat menggunakan botol plastik, paralon, ranting pohon dan sebagainya yang sekiranya dapat digunakan dan dapat dimanfaatkan dalam permainan ini. 
Pada komponen tes lari kombinasi bentuk tes formula 1 kelompok putra memperoleh rata-rata (mean) 22,55 detik, modus 20,07 detik dan normatif berada pada kriteria baik berjumlah 19 orang $(47,50 \%)$ dari jumlah keseluruhan 40 orang, dan pada kelompok putri rata-rata (mean) 23,58 detik, modus 25,19 detik dan normatif berada pada kriteria tidak baik berjumlah 14 orang $(40,00 \%)$ dari jumlah keseluruhan 35 orang.

Penyebab dari hasil analisis data yang dominan memperoleh hasil kriteria tidak baik adalah pada tes tersebut jarang diberikan oleh guru sehingga siswa tidak mendapatkan hasil yang maksimal saat dilakukan tes. Hasil analisis data yang memperoleh hasil kriteria baik disebabkan karena lari ialah gerakan yang sangat mudah dilakukan tanpa latihan semua siswa bisa melakukan gerakan lari.

Agar latihan yang dilakukan bisa membuahkan hasil yang maksimal terhadap gerak dasar yang dibutuhkan dalam olahraga atletik, maka perlu melakukannya dengan berpedoman pada prinsip-prinsip latihan yang sesuai dengan kondisi tingkat pertumbuhan dan perkembangan, kematangan, usia dan antropometri tubuh.

\section{Simpulan}

Berdasarkan analisis data penelitian kemampuan gerak dasar kids atletik yang dilaksanakan pada siswa SD di kecamatan Sukun kota Malang dari keseluruhan hasil tes yang terdiri dari 75 siswa, 40 siswa putra dan 35 siswa putri simpulan hasil penelitian adalah (a) gerak dasar lari bentuk tes kanga's escape domain tes berada pada kategori baik jumlah 30 orang (40\%), (b) gerak dasar lompat berupa tes loncat katak domain tes berada pada kategori baik jumlah 32 orang $(42,7 \%)$, (c) gerak dasar lempar hasil tes lempar turbo domain tes berada pada kategori kurang jumlah 40 orang $(53,3 \%)$, hasil tes lari formula 1 domain tes berada di kategori baik jumlah 27 orang (36\%).

\section{Daftar Rujukan}

Emral. (2017). Basic Concepts in Physical Exercise on Sport. In: Proceeding International Scientific Seminar on Sport and Sportsciences.

Hidayat, S. (2014). Pelatihan Olahraga Teori dan Metodologi. Graha Ilmu.

Hindriani. (2018). Analisis Kemampuan Kids Atletik Pada Siswa Sekolah Dasar Di Kota Bengkulu. Jurnal Ilmiah Pendidikan, 1(3), 23-31.

Kemenpora. (2009). Undang-undang Sistem Keolahragaan Nasional.

Khairuddin. (2017). Olahraga Dalam Pandangan Islam. Jurnal Olahraga Indragiri.

Mardiana, A. (2014). Pendidikan Jasmani dan Olahraga. Universitas Terbuka Malang

Meirawati, N., \& Nurrochmah, S. (2020). Kemampuan Kecepatan Gerak Dan Daya Ledak Otot Siswa PPLP Jatim Di Kediri Cabang Olahraga Atletik. Gelanggang Pendidikan Jasmani Indonesia, 4(1), 28-34.

Mirhan. (2016). Hubungan Antara Percaya Diri dan Kerja Keras Dalam Olahraga Dan Keterampilan Hidup. Jurnal Olahraga Prestasi, 12(1), 1.

Nurrochmah, S. (2016). Tes dan Pengukuran dalam Pendidikan Jasmani dan Keolahragaan. UM Press.

Plowman \& Smith. (2017). Exercise Physiology For Health, Fitness, and Performance. Wolters Kluwer.

Purnama, D. (2010). Cermat Memilih Sekolah Menengah Yang Tepat. Gagas Media.

Rumini. (2014). Pembelajaran Permainan Kids' Athletics Sebagai Wujud Pengembangan Gerak Dasar Atletik Pada Anak-Anak. Journal of Physical Education, Health and Sport, 1(2), 106-107.

Septiria. (2020). Pengaruh Latihan Model Lompat Tali Berpasangan Dan Ladder Drill Terhadap Peningkatan Kids Atletic. Jurnal Pendidikan Jasmani, Olahraga dan Kesehatan, 4(1), 168-182. 